\title{
Reasons for Why Gaza Palestinian Immigrants Select Belgium as Asylum Destination: A Palestinian Oral History Study
}

\author{
Jehad Suleiman Salem Al-Masri \\ Al-Quds Open University, Rafạ Branch, Gaza Strip, Palestine \\ *Corresponding author: Jehad Al-Masri \\ jalmasri@qou.edu
}

\begin{abstract}
:
This study deals with a sensitive issue related to the prevailing thinking among the residents of Gaza Strip. Some of them seek to reach to Belgium as a temporary refuge due to the difficult living conditions in Gaza resulting from the intense political rivalries which led to an internal conflict between Fateh and Hamās. This conflict negatively affected all life aspects, worsened by the Gazan's loss of hope for a breakthrough for the crisis in the foreseeable future. Another group of Gaza Strip residents want Belgium as their permanent home which can relieve them from the complex and long lasting conditions due to the Israeli occupation. Their feelings are coupled with their despair of having an independent Palestinian state in which they can live a normal life. The study is based on oral interviews conducted by the researcher with a sample of male and female residents in Gaza Strip. The interviewees come from different age groups aspiring fir asylum in the European countries, with preference to Belgium. The importance of this study lies in its being a reference for the Belgian Immigration Office to understand the nature of the factors, circumstances, and objectives behind the Gazan's selection of Belgium as asylum destination than other European Union countries. The study is also a detailed scientific study for the aspiring residents of the Gaza Strip who seek asylum in Belgium. It aims to offer them a better understanding of the nature of asylum in Belgium. Their understanding of the nature of immigration to Belgium was influenced by unofficial sources such as some relatives, acquaintances and colleagues who succeeded in achieving their goals in Belgium. The Gazans aspiring for asylum in Belgium focused on the privileges in Belgium, and ignored the circumstances that helped their peers to succeed in obtaining asylum in Belgium. The conditions which helped their countrymen to succeed in Belgium may not apply to them given that the laws of asylum in Europe change dramatically from time to time under the political, social and demographic conditions. The Gazans aspiring for asylum in Belgium ignored the shortcomings and failures of asylum and integration and did not have the criteria to differentiate between the countries of asylum in the European Union. Belgium became their preferred asylum destination.
\end{abstract}

Keywords: asylum, immigration, Belgium, Gaza Strip, oral history 


\section{Introduction:}

Having a long experience in the Palestinian oral history when working as the manager of the Palestinian Oral History Center in the Gaza Strip, I published a number of papers and books, delivered lectures and participated in seminars and workshops discussing a number of topics related to the Palestinian oral history. I lived for some time in the city of Liège as a Ph.D. scholar in history but had to quit the study for political, social and economic reasons. I meant a number of the Palestinian refugees in Belgium and others in Gaza wishing to immigrate to Belgium. In addition, I am aware of asylum laws in place in Belgium through reading about such laws in Dublin Regulation and the information provided by the Palestinian immigrant in Belgium. Such information provided me with rich knowledge on why do Gazans choose to seek asylum in Belgium as compared to other European countries.

\section{Statistical analysis of the oral interviews}

2.1 Numbers and percentages of males and females interviewed orally from different age groups:

- The number of the persons interviewed orally was (100) people from the towns, villages and camps of Gaza Strip, divided as follows:

- (60) male, distributed as follows:

- The number of males aspiring to immigrate to Europe was (20) out of (60), $(33.33 \%)$.

- The number of males who refused the idea of immigration to Europe was (28) out of (60), (46.67\%).

- The number of males who were hesitant and could not choose between staying in Gaza Strip or immigrating to Europe was (09) out of (60), (15\%).

- The number of males who refused the interview was (03) out of (60), (05\%).

- (40) female were divided as follows:

- The number of females aspiring to migrate to Europe was (10) out of (40), (25\%).

- The number of females who refused the idea of emigration to Europe was (20) out of (40), (50\%).

- The number of females who were hesitant and could not choose between staying in the Gaza Strip or immigrating to Europe was (04) out of (40), (10\%).

- Number of females who refused to be interviewed was (06) out of (40), (15\%).

\subsection{Criteria for interview:}

- Differences were observed in the selection of male and female respondents in terms of: age, occupation, place of residence, sex, social status, financial and educational level.

- Males were classified into three age groups for the necessities of the research relating to the differences in attitudes, goals and considerations. The females were not classified into age groups as the percentage of them aspiring to emigrate to Europe is very small as a result of specific social factors which we will explain later.

- The conducted oral interviews with three age groups, each constituting a whole generation. Each age group consisted of (20) males. The age groups were divided as follows:

1. The first age group: (21-35) years.

2. The second age group: (36-50) years. 
3. The third age group: (51-65) years.

\section{Males aging (21-35) years}

3.1 Numbers and percentages of males aging (21-35) years according to their preferences, wishes and objectives:

- The number of males aspiring to migrate to Europe was (11) out of (20), (55\%).

- The number of males who rejected the idea of immigration to Europe was (05) out of $(20),(25 \%)$.

- The number of males who showed a reluctance and did not choose between staying in the Gaza Strip and immigrating to Europe was (03) out of (20), (15\%).

- The number of males who rejected to be interviewed was (01) out of (20), (05\%).

- The focus of this age group will be through details about the numbers, percentages and explanations as this age group tops the groups aspiring to immigrate to Europe.

3.2 The factors, circumstances and considerations behind the high percentage (55\%) of males aging (21-35) aspiring to immigrate to Europe:

1. The high rate of unemployment among the educated and professionals due to the siege imposed on the Gaza Strip since Hamās takeover in 2007 (Hammad, November 2016).

2. Lack of employment opportunities in the education and health sectors, given that most university graduates hold specialized degrees in these two fields.

3. The failure of many graduates to obtain academic employment opportunities in the Palestinian universities in the Gaza Strip, having spent many years in exile and paying large sums of money for education. This is coupled with the culture of social disadvantage in when working in professions not suitable for their scientific status. This increases their suffering and narrows the work spaces available in simple occupations.

4. The scarcity of graduate programs in Palestinian universities in most disciplines, especially scientific and applied, motivates aspiring students to seek opportunities to exit the Gaza Strip in order to complete their higher studies in Europe knowing the high cost of study at Arab universities and the restrictions relating to admissions and stat (Zīdān, January 2017).

5. The scarcity of programs supported by donor countries for temporary employment of university graduates.

6. Restrictions on political and social freedoms since Hamās takeover of Gaza Strip in 2007.

7. Loss of hope for building a promising and simple future in the near future to the extent that marriage and owning a simple home has become a dream.

8. The lack of good entertainment activities where Gaza Strip turned into a large prison.

9. Difficulty in relying on the parents due to the limited income, and the large responsibilities resulting from the large number of family members.

10. The belief that the conflict between Fateh and Hamās will prolong the division between the Gaza Strip and the West Bank. This foreshadows a dark future in the Gaza Strip under the siege.

11. Restricting opportunities for jobs in the security services in the Gaza Strip to Hamās affiliates. This means that there are no opportunities in this field for members of other parties. 
12. The shut-down of most of the internationally supported Non-governmental organization (NGO) that operated in the Gaza Strip before the Hamās takeover in 2007. This increased the unemployment rate among young people.

13. The lack of Arab recruitment missions in the Gaza Strip in education, health, and other sectors which such opportunities are abundant for Jordanian and Egyptian and other citizens.

14. Lack of national, regional and international care for artistic, sports, musical and other professionals in the Gaza Strip (Hammad, November 2016).

15. The small area of the Gaza Strip, $(365 \mathrm{~km} 2)$, restricting movement and labor, let alone over-crowdedness.

16. Power outages in Gaza Strip for long hours worsen life conditions in summer and winter.

17. The absence of an airport and port to ease travelling for study, tourism, visit and treatment.

18. The separation between the Gaza Strip from the West Bank due to division and occupation led to the lack of employment opportunities for the Gazans in the West Bank given that it is a larger area $(5655 \mathrm{~km} 2)$ and more vital in its economic activity compared to Gaza Strip $(365 \mathrm{~km} 2)$.

19. The prevention of working in Israel since the outbreak of the second Intifădah in 2001. The wages of Palestinian workers in Israel used to be very high which made some Gazans prefer working in Israel to immigration and asylum in terms of financial income and comfortable working conditions.

20. The suspension of civil status procedures for family reunification and issuance of personal cards by the Israeli authorities since 2001 due to the outbreak of the second Intifădiah. This prevented a number of Gaza Strip citizens returning to Gaza from obtaining any document allowing them to travel through the crossings. This deprived many of travelling for study, visit and treatment.( Aliskāfî, February 2017).

21. The closure of Rafah crossing almost permanently throughout the year. It is the only land crossing connecting Gaza Strip to the outside world.

22. The unstable situation ranging between peace and war between Hamās and Israel, making the Gaza Strip a dangerous war zone throughout the year.

23. The diminishing The United Nations Relief and Works Agency for Palestine Refugees in the Near East (UNRWA) role in assisting the Palestinian refugees in the Gaza Strip.

24. The difficulty of entering into commercial projects in the Gaza Strip due to deteriorating economic conditions.

25. Parents encouraged their male children to seek asylum in Europe. Some parents fund their sons' journeys for asylum despite their familiarity with the risks and the possibility of failure. The circumstances forced the parents to take the adventure and accompany their children on death boats in seas and oceans.

3.3. Conclusion: From the above, we can conclude by analyzing the content of the oral interviews conducted with this age group of males aging (21-35) aspiring to emigrate to Europe, that they were surrounded by extremely harsh conditions forcing them to adopt thinking to escape from the dire political, military and economic conditions that prevail in the Gaza Strip because of the harsh siege imposed since the Hamās takeover of Gaza in 2007 (Zīdān, January 2017 \& Hammad, November 2016). 
The situation gradually worsened in Gaza evidenced by the fact that the number of young people who left the Gaza Strip towards Europe in the period between the coming of Palestinian National Authority in 1994 and 2006 before the Hamās takeover of the Gaza Strip was very small. Reaching Europe during that period was easy, inexpensive and safe where people could obtain European tourist, study, and commercial and treatment visas. Most of those who traveled to Europe in that period (1994-2006), as students, tourists, visitors, traders or patients, returned to the Gaza Strip without considering asylum (Gharāybah, February 2010). The small percentage of asylum seekers in that period had different goals to the present asylum goals. Their asylum aimed to improve their living conditions, enjoy wider freedoms in European societies, or simply for getting used to the European lifestyle. Contrary to that, Gazans now seek Europe to escape their bitter and dark reality. Those who come to Europe officially on education, tourism, visit, treatment and trade visas are seriously considering not returning to the Gaza Strip and seek alternatives that offer them permanent residency opportunities in Europe through marriage, work and asylum (Hammad, November 2016).

3.4. The factors, circumstances and considerations behind the very low percentage $(25 \%)$ for males aging (21-35) who rejected the idea of immigrating to Europe:

1. Their affiliation to a Palestinian political party necessitates their stay in the Gaza Strip.

2. Their affiliation to a military wing of a Palestinian political party that prevents them from traveling through the Gaza Strip crossings for security grounds and their fear of being arrested while coursing the Egyptian and Israeli crossings.

3. Their belief that Palestine is a land of Ribāt (places of worship for Sufi ascetics and fighters for the sake of Allāh) and they therefore must be settled in order to win the remaining life of the Hereafter and enjoy the eternal life.

4. Their inability to accommodate themselves to the nature of European lifestyle in terms of customs and traditions, especially with regard to the general freedoms available to females. Some Arab and Muslim parents living in European countries, after obtaining their citizenship through asylum, committed crimes against their daughters who exceeded the limits of the Arab social customs (Belgian Immigration Office, May 2017).

5. Their lack of skills and professions that enable them to integrate into the European societies easily and quickly (Okal, April 2008).

6. Their working in good and appropriate jobs, or successful commercial projects, property, real estate, buildings and land they obtained through work, commerce and inheritance.

7. Their preference to live with their families, relatives, acquaintances and colleagues in the Gaza Strip.

8. Their love for the daily life in the Gaza Strip despite their poor military, political and economic conditions. They do not believe that any place in the world can replace their homeland.

3.5. Conclusion: We can conclude by analyzing the content of oral interviews conducted with this group of males aging (21-35) who rejected the idea of migration to Europe that they had decided to reject the idea for certain factors and considerations. It is expected that some of them may join those aspiring to 
emigrate to Europe if the factors and considerations that prevent them from thinking of emigrating to Europe change. However, some of them stress their absolute rejection of the idea of asylum in Europe due to their firm belief in the necessity of stability in the land of Ribāt which they should liberate from the occupation.

\section{Males aged (36-50) years}

4.1 The numbers and percentages of males aging (36-50) years according to their preferences, wishes and objectives:

- The number of males aspiring to migrate to Europe was (06) out of (20), (30\%).

- The number of males who rejected the idea of immigration to Europe was (09) out of $(20),(45 \%)$.

- The number of males who showed a reluctance and could not choose between staying in the Gaza Strip and immigrating to Europe was (04) out of (20), (20\%).

- The number of males who refused to be interviewed was (01) out of (20), (05\%).

4.2 Factors, conditions and considerations behind the low percentage (30\%) among the males aged between (36-50) aspiring to immigrate to Europe:

1. The desire to ensure a scientific, healthy and professional future for the members of their families in the European countries known for their care to their citizens in all walks of life.

2. Fear for the future of their young children in a society where partisan, political and military conflicts and polarizations are dominant.

3. Their dissatisfaction with job and living conditions and their ambition to improve their working and living conditions.

4. Having nothing to lose in the Gaza Strip but a job salary.

5. Securing better opportunities in the European societies in terms of freedom, education, work, travel and tourism.

6. Their desire to enjoy the European life, especially those who worked and studied for several years in a European country.

4.3 Conclusion: We can conclude by analyzing the content of oral interviews conducted with this age group of males aging (36-50) aspiring to immigrate to Europe that they wait for a golden opportunity to reach Europe and seek asylum. They seek suck asylum in the light of their realizing that their financial and living conditions in Europe for children's future will be better than in the Gaza Strip. So they do not want to risk so that they do not lose the advantages in the Gaza Strip.

4.4. Factors, conditions and considerations behind the high percentage of $(45 \%)$ among males aging (36-50) who refused to immigrate to Europe:

1. Working in government and private jobs prevents them risk loss after having spent long time in employment. They fear losing their retirement pension that will be their only financial income in their old age.

2. Their work in prestigious official and social positions in the Gaza Strip which cannot be found in Europe through asylum.

3. The fear of their children, especially females, integration into the free European lifestyle. They may regret socially and religiously if they lose their children who are considered the asset of the Palestinian family.

4. Their fear from the possibility that some European asylum countries may adopt their children officially if they are disciplined in the usual ways in Arab societies. 
5. Fear of being unable to integrate into the European societies after becoming accustomed to the Palestinian-Arab lifestyle.

6. Fear of failure to learn the languages of the communities in which they live, thus reducing the chances of finding suitable jobs.

4.5 Conclusion: We can conclude by analyzing the content of oral interviews conducted with this age group of males aging (36-50) who refused the idea of immigration to Europe that in the event some of them lose the privileges they enjoy in the Gaza Strip, they might start considering and planning for reaching Europe to seek asylum there. After reaching Europe, they will start thinking about alternatives to mitigate the effects of the European life for their children through the follow-up of their social up-bringing, awareness of their Arab Islamic values and social customs within the family. They can also seek to enroll them in Arab schools, mosques and Islamic centers. In addition, they may think of leaving the European country of asylum after obtaining their citizenship and return home or travel to a Gulf country to stay and work there which becomes easier for them after obtaining the European passport. Holders of Palestinian travel documents and Palestinian passport find it difficult to obtain visas to enter most of the Arab Gulf countries and to reside and work in them. They can travel to one of the Arab countries hosting the Palestinians to establish an investment project and stay after being deprived of the right of citizenship, work, study and treatment on pretexts to protect their right of return (Ghareeb, March 2016 \& Akram, January 2008). In addition, they can travel to other European countries to stay, especially countries having Islamic schools and centers so that their children can join such schools.

\section{Males aging (51-65) years}

5.1 The numbers and percentages of males aging (51-65) years according to their preferences, wishes objectives:

- The number of males aspiring to migrate to Europe was (03) out of (20), (15\%).

- The number of males who rejected the idea of immigration to Europe was (14) out of $(20),(70 \%)$.

- The number of males who showed reluctance and could not choose between staying in the Gaza Strip and immigrating to Europe was (02) out of (20), (10\%).

- The number of males who refused to be interviewed was (01) out of (20), (05\%).

\subsection{The factors, circumstances and considerations behind the very low rate of} (15\%) for males aging (51-65) who showed an ambition to immigrate to Europe:

1. Their desire to join the rest of their family members in Europe if they no longer have a breadwinner who cares for their health and life affairs in Gaza Strip.

2. People suffering from incurable and dangerous diseases desire to obtain advanced, effective and free treatment in light of the lack of medical expertise in the Gaza Strip, the lack of advanced medical equipment for treating such diseases, the high financial costs of treating such diseases in hospitals in the Gaza Strip and the difficulty of obtaining official approvals for external medical transfers to Egypt, Jordan and Israel. This is coupled with Israel's occasional refusal to allow patients to enter the Erez crossing for treatment in hospitals in Israel, the West Bank and Jordan under security pretexts. This is also added to Egypt's closure of the Rafah crossing for long periods where patients wait too long. 
3. Their desire to obtain a European passport that enables them to travel and enter many countries without restrictions to visit their children and relatives residing in other countries for many years. They also wish to meet their grandchildren whom they never met except seeing their photos through social networks. Their Palestinian passport does not enable them to enter those countries to visit their children and grandchildren, and does not allow them to attend their events such as weddings and graduation from universities.

4. Escaping the social, economic and political crises in the Gaza Strip fearing social, political and judicial punishment in cases of bankruptcy, corruption, bribery, manipulation, forgery, honor and treason.

5. Escaping the religious and social isolation where most of these cases were confined to the Christian minority in the Gaza Strip.

5.3 Conclusion: We can conclude by analyzing the content of oral interviews conducted with this age group of males between (51-65) aspiring to Europe that asylum opportunities, if available, are considered an appropriate way to alleviate the political, social, health and financial burdens which they experienced in the Gaza Strip due to the dire economic, political and social conditions. They are therefore willing to leave their long-standing legacy in the Gaza Strip and rush to risk being into an unknown world at this advanced age in which people tend to settle down.

\subsection{Factors, circumstances and considerations behind the very high percentage} (70\%) for males aging (51-65) who rejected the idea of immigration to Europe:

1. The inability to cope with the suffering of travel and alienation at such an old age, for reasons related to the diseases of aging, especially diabetes, pressure, heart diseases and cancer spread in the Gaza Strip due to poor health care and lack of medical services, let alone the pressures of living in an environment lacking basic elements of human life.

2. The lack of ambition to achieve in the foreign country at such an old age which does not give them room for new adventures. In such an age, they no longer assume responsibility for the future of their children and dependents as most of them become mature, independent and can shoulder their own responsibilities.

3. Their inability to integrate into foreign communities in terms of languages, customs and traditions at such an old age.

4. Their preference to a life of stability, close relation with friends of their age and devotion to worship.

5. Their physical inability to endure the hardships and risks of escaping to Europe illegally (Alhāj, July 2009 \& Hammad, November 2016).

5.5 Conclusion: We can conclude by analyzing the content of oral interviews conducted with this age group of males aging (51-65) who refused the idea of emigration to Europe that they do not want to leave the Gaza Strip despite all the encouraging conditions for leaving it. Given the age factor, Gaza remains a better place for them. In terms of the alternatives available to them to overcome the difficult conditions in the Gaza Strip, they believe in fate and their dependence on their children which is a feature of the coherent social structure (Ghareeb, March 2016). 
6. Males and females aged between (21-65) who showed reluctance and could not choose between staying in the Gaza Strip and immigrating to Europe

6.1 The numbers and percentages of males and females who showed reluctance between staying in the Gaza Strip and immigrating to Europe:

- The number of males and females who showed reluctance between staying in the Gaza Strip and immigration to Europe was (13) out of (100), (13\%) distributed as follows:

- The number of males who showed reluctance between staying in the Gaza Strip and immigration to Europe was (09) out of (60), (15\%).

- The number of females who showed reluctance between staying in the Gaza Strip and immigrating to Europe was (04) out of (40), (10\%).

6.2 The factors, circumstances and considerations behind the very low percentage (13\%) for males and females aged (21-65) who showed reluctance between staying in the Gaza Strip and immigration to Europe:

1. Waiting for good and suitable job opportunities in the field of their specialization in light of the regional and international promises which the media circulate around the clock to support the Gaza Strip, rebuild its infrastructure and improve its economic conditions.

2. Their being engaged to girls with whom they have strong relationships, which makes it difficult for them to leave.

3. They do not have the financial ability to cover travel expenses of illegal immigration routes.

4. Their enrollment in university studies and their fear of losing the years of study which they completed in Gaza Strip universities.

5. Their unfamiliarity with the nature of life in Europe as they have no previous experiences in traveling to Europe.

6. Their religious and moral attachment to their families, especially those who care for their sick parents or their being the sole breadwinners of their families.

7. Their fear of illegal migration and the risks they entail.

8. There are special social considerations related to females in addition to the factors and circumstances mentioned above. The society does not allows girls to travel alone and being away from their families for fear of honors issues which causes bad reputation to their families and limits their chances of getting married. Their sisters also may find it difficult to marry. Some of these girls get married early which prevents them from leaving family members. Moreover, the husband, socially, does not bear the responsibilities of the wife in case of her failure to perform her duties except in rare and emergency cases.

6.3 Conclusion: We can conclude by analyzing the content of interviews conducted with this age group of males aged (21-65) who showed reluctance between staying in the Gaza Strip and migration to Europe, that they were controlled by their considerations of profit and loss factors and other factors related to the financial abilities. In the event of having less financial abilities, this percentage may be added to those males wishing to migrate to Europe. As for the females who showed a reluctance between staying in the Gaza Strip and migration to Europe, some single women hope to get married to people holding European passports. Those married prefer to be reunited with their husbands through asylum or, conversely, to reunite their husbands by resorting to asylum if their 
husbands agree to have them seek asylum Europe first, knowing that the European asylum countries sympathize with female and child asylum seekers.

7. Males and females aging (21-65) who refused to be interviewed orally

7.1 The numbers and percentages of males and females who refused to be interviewed orally:

- The number of males and females who refused to conduct oral interviews was (09) out of (100), (09\%) distributed as follows:

- The number of males who refused to conduct oral interviews was (03) out of (60), $(05 \%)$.

- The number of female respondents who refused to be interviewed orally was (06) out of (40), by (15\%).

7.2 Factors, circumstances and considerations behind the very low percentage (09\%) for males and females between the ages of (21-65) years who refused to be interviewed orally:

1. They feared revealing their secrets about this sensitive topic, although the researcher informed them that their names would be confidential.

2. They believe that such oral interviews will not alleviate their suffering, cure their problems, or help them gain anything they are looking for.

3. They are not interested in such subjects, which they did not think about at all due to the constant preoccupation with providing a living for their family members. .

4. Their lack of interest in such subjects as their family circumstances and their financial situation do not allow them to immigrate. They are not motivated to know further details.

5. There are special social considerations related to females in addition to the factors and circumstances mentioned above. The strict social norm prevents females from expressing their opinions on such subjects, especially in a society whose members are known to each other.

7.3. Conclusion: We can conclude by analyzing the content of oral interviews conducted with this age group of males and females between the ages (21-65) who refused to conduct oral interviews that they had decided to refuse for certain factors which forced them to refuse being asked suck questions. Their complex problems dominated their thought. The researcher thinks that if they are freed a little from such pressures, they would accept to be interviewed.

\section{Factors behind the differences in the responses of interviewees}

8.1. Age factor: The percentage of males between the ages of (21-35) years who had an ambition to migrate to Europe was very high compared to other age groups due to many factors explained in detail above.

8.2 Sex factor: The percentage of males who showed an ambition to migrate to Europe is very high compared to the percentage of females due to many factors explained in detail above.

8.3 Profession factor: The percentage of the unemployed aspiring to improve their professional and financial career who have shown an ambition to immigrate to Europe is very high compared to those working in higher academic and diplomatic professions and official centers due to factors classifying them within the upper strata of society. They cannot ensure such a status in the asylum country. 
8.4 Place of residence factor: The percentage of the residents of Gaza Strip camps and neighborhoods of marginalized cities who have shown an ambition to immigrate to Europe is very high compared to the residents of urban neighborhoods due to factors related to financial and living conditions. Those living in camps do not possess real estate, land and commercial projects and they also have no near promising future in Gaza Strip.

8.5 Social status factor: The percentage of single young men who have shown an ambition to immigrate to Europe was very high compared to married couples due to factors related to the lack of social and financial responsibilities they might leave behind if they leave Gaza Strip. They also have better chances for adventure. The percentage of married women was very high compared to single females due to factors related to social scandals if single females were allowed to leave alone. As for married women, they seek to agree with their husbands to allow them to immigrate to Europe so that they can help their husbands and children travel to Europe through reunion. Women chances of asylum approval is higher than those of males due to the sympathy of European countries with women and children.

8.6. Education level factor: The percentage of those who did not complete university education who showed an ambition to immigrate to Europe was higher than those with a diploma and a bachelor's degree because they did not expect job or professional opportunities. In Europe, they believe they would be provided with social assistance. The percentage of graduates with higher degrees (M.A and PhD) was the least ambitious to immigrate to Europe. Those highly educated and unemployed believe that their higher degrees must help them secure employment opportunities that suit their qualifications. Therefore, their waiting is a golden opportunity for them which they are not ready to trade with leaving to Europe because of the lack of opportunities to obtain jobs in European universities. They do not speak the languages of most asylum countries which condition employment to proficiency in languages. Those securing a job among the holders of higher degrees do not think of seeking asylum. However, if their lives are seriously threatened due to their ideology and practice in an environment full of partisan conflicts, they will prefer immigrating to all the financial, social and scientific benefits they enjoy and which they will never enjoy in the countries of asylum.

9. The factors, circumstances and considerations behind Gazans' selection of Belgium as asylum destination

9.1 The numbers and percentages of males and females who showed ambition to immigration to Europe, preferring Belgium:

- The number of males and females of all age groups who showed ambition to immigrate to Europe, preferring Belgium in particular was (19) out of (30), $(63.33 \%)$.

- The number of males of all age groups who showed ambition to migrate to Europe, preferring Belgium in particular was (13) out of (20), (65\%), distributed as follows:

- The number of males aging (21-35) years who had an ambition to immigrate to Europe, preferring Belgium in particular was (08) out of (11), (72.73\%)

- The number of males aging (36-50) years who showed ambition to immigrate to Europe, preferring Belgium was (03) out of (06), (50\%)

- The number of males aging (51-65) years who had an ambition to immigrate to Europe, preferring Belgium in particular was (02) out of (03), (66.67\%). 
- The number of females who showed an ambition to immigrate to Europe, preferring Belgium in particular was (06) out of (10), (60\%).

9.2 The factors, circumstances and considerations behind the high percentage $(63.33 \%)$ for males and females of all age groups who showed ambition to immigrate to Europe, preferring Belgium in particular:

The analysis of the contents of the interviews conducted by the researcher with the sample of the study shows that a very high percentage of the population of the Gaza Strip seeks asylum in Belgium and prefer it to other EU countries, especially males aging (21-35) years. Some other countries such as Sweden, Norway, Iceland, the Netherlands, Norway and Germany, provide refugees with social assistance which equals what Belgium provides to them. It seems that the material issue, despite its importance and necessity in the light of the harsh siege, was not the decisive factor for Gazans seeking asylum in a particular country. They seek an environment which respects their humanity rather that considerations of material issues. The researcher identifies the factors, circumstances and considerations which made Belgium top the percentages of asylum countries. These factors can be summed up as follows:

1. There is a misconception among people that the origin of the Palestinians is Belgian. This is linked to the assistance provided by Belgium to the Palestinian refugees in Jordan, Syria and Lebanon after the Palestinians were expelled from their homes by the Israeli occupation in 1948. The assistance items used to have signs reading 'Made in Belgium' The Palestinian refugees used to see aid materials in the market to buy other materials. The residents of Jordan, in particular, called the Palestinians the Belgians because the Belgian goods were associated with the Palestinians. Another groups claim that calling the Palestinians Belgians is related to the fact that the Belgians were the first to flee to France because of the German Nazi occupation in 1940. Their crisis then is similar to the Palestinian Nakbah (Catastrophe). Yet another group claims that the name given to the Palestinians in this context relates the Palestinian militias use of the Belgian guns. This popular belief may have given preference to Belgium to other European countries as a country of refuge.

2. The way Gazans' think is similar to their predecessors without taking other options into consideration.

3. The short period taken to consider asylum applications in Belgium compared to other European countries of asylum, and the rare cases of Belgium's refusal of asylum applications of Gaza Strip residents compared to Switzerland, Austria, Luxembourg, Germany, France and Norway. They are considered stateless under 1954 and 1961 Conventions (Akram, January 2008, Okal, April 2008 \& Hammad, November 2017). Belgium considers that these Palestinians need more protection in the light of the harsh conditions knowing that UNRWA, established by the United Nations Relief and Works Agency for Palestine Refugees after the 1948 Nakbah, cannot alleviate the refugee asylum. UNRWA is not a substitution to the countries to which Palestinians immigrate in Europe. (Akram, January 2008 \& Abdu'l Lațîf, 2000/2001).

4. Palestinians benefit from the special and quick asylum procedures granted to them at the country international airport.

5. The Belgian government treats the children of Arab refugee families in a better way compared to Sweden and Norway. It does forcefully adopt the immigrants' 
children when they are disciplined through the usual Arab methods that are cruel and inhuman according to the European laws.

6. Belgium's climate is similar to the Mediterranean climate, unlike Sweden, Norway and Iceland, which have a long and harsh winter climate, which mixes night and day.

7. Belgium is located in the middle of the European continent which allows the Palestinian refugees to travel among European countries to visit their children, acquaintances and relatives in Europe, unlike Sweden, Norway and Iceland, which they consider to be the most northern European countries.

8. The nature and daily life of Belgium are beautiful, where Palestinians can feel the Eastern life because of the large community of Arabs, especially Moroccans and Algerians. This makes life easier for them without the need to master the Dutch or French. This helps bridge the social and cultural gap. These benefits are not available in other asylum countries such as Sweden, Norway and Iceland (Okal, April 2008 \& Hammad, November 2017).

9. The Palestinians can benefit from the social assistance to refugees which is attractive and permanent. This provides them with a comfortable life compared to temporary privileges enjoyed by refugees in other countries of asylum such as Bulgaria, Poland, Hungary, Greece and Spain.

10. The refugee camps in Belgium, in terms of treatment, shelter, food, freedom of movement and work, are better than other European asylum countries such as Bulgaria, Greece, Hungary and Greece (Schockaert, November 2013).

11. Belgium often disregards Dublin's fingerprint for Palestinian refugees in another country. It does not deport them to the state of the fingerprint. This is a privilege for many Palestinian refugees who have been forced to register their fingerprints in countries that were just transit countries to Belgium, Spain, Greece and Italy.

12. It is easy fulfill the basic needs in Belgium in the presence of a large Arab community working in most professions, especially Moroccans and Algerians. This exempts Palestinians from the need to learn basic French and Dutch as soon as they come to speak to others to fulfill their needs.

13. Religious freedom is available in Belgium. It is the first European country to recognize Islam as an official religion in 1968. The country included religious sciences in the curricula of Muslim students under the supervision of the Islamic Cultural Center. A number of its universities, such as Liège and Louvain, teach Arabic (Gharāybah, February 2010). This is added to the Islamic centers, societies, libraries and schools which help them practice their religious rites and enroll their children in Arab schools to preserve their mother tongue, customs and ArabIslamic traditions (Okal, April 2008).

14. A number of relatives and acquaintances of Palestinian refugees are present in Belgium, making it easier for refugees to travel, receive support through money and information.

15. The Palestinian find it easy to cross to Belgium from the transit countries, especially from Turkey, Greece, Italy, Spain and France compared to the difficulty and risk of reaching Sweden, Norway, Iceland and England (Alhāj, July 2009 \& Hammad, November 2016).

16. The ease and speed of the procedures for reunification of refugee families. Belgium does not stipulate conditions for refugees wishing to reunite with their families, while Denmark, Norway, the Netherlands and Norway require that refugees wishing to reunite their families learn the language, achieve a certain level of integration, among other conditions. These are difficult conditions for the 
refugees to fulfill in order to meet their families in a timely manner. Therefore, most of the married Gazans aspiring to immigrate to Belgium consider taking the adventure alone without taking their wives with them in order to reduce the high costs and to prevent their family members from experiencing the risks of illegal immigration to Belgium. They seek to have their asylum applications approved and afterwards bring their family members and have the Belgian government pay the costs. They sometimes take one child with them to accelerate the process of having their applications approved.

17. The residence permits Belgium grants to refugees are permanent. Obtaining a Belgian citizenship requires three to five years of stay in the country without other conditions. Other European countries grant temporary residence permits to the refugees and require spending many years to obtain a citizenship.

18. The cities and villages of Belgium are vibrant, connected and crowded; unlike Sweden, Norway and Iceland, where rural life prevails over most of its territory.

19. Some Palestinian refugees are fluent in French adopted in Belgium, others are familiar with its basics. French is a living language compared to Swedish, Norwegian, Danish, Polish, Hungarian and Bulgarian. Therefore, refugees consider studying and mastering these languages a waste of time and effort. .

20. The solidarity of some members of Parliament and other institutions, associations, unions and intellectuals in Belgium with the cause of the Palestinian people (Gharāybah, February 2010) in addition to the assistance that Belgium provides to the Palestinians in all aspects of life is reflected in the Gazans support of Belgium's football team at the World Cup, as if they are fully encouraging their team.

21. Single refugees can get married Belgium brides of Palestinian and Arab origin due to the large number of Palestinian and Arab families living in Belgium, compared to Switzerland, Austria, Denmark and Luxembourg (Alhâaj, July 2009).

10. Conclusion: The researcher identified important findings regarding the preference of the Palestinian residents of the Gaza Strip to Belgium as an asylum country. After analyzing the content of the oral interviews with a sample of Gazans aspiring to immigrate to Belgium, another sample of asylum seekers in Belgium, another sample of persons holding Belgian permanent residence by asylum and another sample of Belgian nationals, the researcher found that the factors, circumstances, objectives and considerations that governed the mentality of the Gaza Strip residents aspiring to immigrate and seek asylum and their choice of Belgium asylum country rather than other European asylum countries lie in two main advantages. The first is the encouragement confirmed by the Palestinian refugees in Belgium about the high rate of acceptance of applications for asylum for the residents of the Gaza Strip in particular, as there is priority in accepting their asylum requests. Therefore, they chose Belgium for fear of registering their fingerprints in other European countries which may reject their asylum application after which they have to return to Gaza. Their return to Gaza is a difficult and unavailable option because of the conditions that forced them to leave their country, and for other reasons related to the difficulty of their return. Most of them got rid of their Palestinian passports before reaching the countries of asylum. It is also difficult for the countries of asylum to deport them as they are stateless. The other option for them is to tolerate the long waiting period of after rejecting their asylum applications. This means that they have to live in the camps away from their families. Another option is the long-term disappearance for fear of detention and deportation in a situation similar to fugitives and 
displaced persons pending the issuance of new laws for the refugees of the Gaza Strip. All of such conditions are difficult for the Palestinian refugees in particular, because they did not aim to escape from the refugees camps in the Gaza Strip to the refugee camps in Europe.

The second privilege for the Palestinian refugees is that Belgium disregards the Dublin fingerprint registered in a number of European countries for refugees from the Gaza Strip, particularly Bulgaria, Greece, Spain and Italy. This prompted asylum seekers from the Gaza Strip who to actively seek asylum in Belgium through transit countries. In addition, other Palestinian refugees who had their fingerprints registered in the transit countries aspire to move to Belgium as their preferred asylum destination.

Another finding by the researcher is that aspiring asylum seekers do not favor asylum in other European countries that often reject Palestinian asylum applications, because they view the Palestinians' problem as an exceptional problem, an international issue for an entire people that should be resolved through the United Nations, not through immigration departments in Europe. In contrast, the Palestinians, especially the people of the Gaza Strip where refugees amount to $80 \%$ or its residents, believe that they are the first among those entitled to the right of obtaining asylum in most European countries for two reasons: First, England should bear the consequences of its policies because it uprooted them from their land and forcibly deported them from their homeland, the most beautiful, sacred and richest land in the world. It turned them into poor and displaced refugees. Moreover, Britain still provides historic support to prolong the Israeli occupation. Other European countries resorted to only condemn the Israeli acts and provide financial support to the Palestinians. This is in light of the US dominance on the Security Council by vetoing any decision against Israel in favor of the Palestinians. The second reason lies in the Palestinians total despair of the United Nations' solution to their cause. They therefore found themselves forced to seek refuge in the European countries to deal with their crises inside Palestine and the Arab host countries by creating humanitarian and political refugee crises within the European countries of asylum. The Palestinians' waves of refuge might be a wake-up call to the tragedy of the last people on this planet who are still under occupation. 


\section{References:}

[1.] Abdu'l Lațîf, R. (2000/2001). The Reality of the Palestinian Asylum and the UNRWA. [Arabic]. Palestine Network for Dialogue. Gaza. [Online]. Available: https://www.paldf.net/forum/showthread.php?t=141949

[2.] Akram, S. (January 2008). Reinterpreting the Palestinian Refugees Rights Under the International Law [Arabic]. Website: group 194. Palestine. [Online]. Available: http://group194.net/article/18286

[3.] Alhāj, S. (July 2009). Refugees to Belgium: Stories of Illegal Immigration [Arabic]. Website: Al-Akhbār Newspaper. Beirut. [Online]. Available: https://al-akhbar.com/Archive Justice/130916

[4.] Aliskāfī, N. (February 2017). Palestinians without IDs in Gaza and not Possible Solution. [Arabic]. Website: Altra Palestine. Palestine. [Online]. Available: https://ultrapal.ultrasawt.com

[5.] Belgian Immigration Office (May 2017). Femicide. [Arabic]. Website: Belgium Network 24 News. Brussels. [Online]. Available: https://goo.gl/NvbtCX

[6.] Gharāybah, I. (February 2010). Palestinians, Arabs and Muslims in Belgium [Arabic]. Website: AlGhad Newspaper. Amman. [Online]. Avialble: http://www.alghad.com/articles/537851

[7.] Ghareeb, Y. (March 2016). Palestinian Refugees in the Arab East: Identity, Space and Place [Arabic]. Website: Alraby Aljadīd. London. [Online]. Available: https://goo.gl/M2HroS

[8.] Hammad, Y. (April 2017). Belgium: the Palestinians Destination to Europe [Arabic]. Website: Al-Akhbar Newspaper. Beirut. [Online]. Available: https://alakhbar.com/Arab/229225

[9.] Hammad, Y. (November 2016). From Gaza to Belgium: An Adventure Lacking Death. Website: Altra Palestine. Palestine. [Online]. Available: https://ultrapal.ultrasawt.com

[10.] Okal, H. (April 2008). Arab Communit in Belgium between Intergration and Isolation [Arabic]. Website: Dīwān Al Arab. USA. [Online]. Available: http://www.diwanalarab.com/spip.php?article13471

[11.] Schockaert, L. (November 2013). Alternatives to detention: open family units in Belgium [Arabic]. Forced Migration Review, No.44, Pp.53-55. Website: Forced Migration Review. University of Oxford. [Online]. Available: http://bit.ly/1I1cjiu.

[12.] Zīdān, B. (January 2017). The Palestinian Artist Fātinah Al Gharrah: The Long Journey from Gaza to Brussels [Arabic]. Website: Al-Ayyām Newspaper. Rāmallah. [Online]. Available: http://www.alayyam.ps/ar_page.php?id=11d3137ay299045754Y11d3137a 
Sample interview questions conducted by the researcher with the sample of the study who preferred Belgium as a country of asylum. The number of interviewees was (19) male and female residents of the Gaza Strip from different age groups and scientific, professional and social levels.

Q 1. Name: $\quad$ Gender: Male, Female Current Residence:

Place of Birth: Date of Birth: Occupation:

Marital Status: Married, Single, Widowed, Divorced

Number, gender, age and social status of family members:

Education Level: Monthly Financial Income: Languages you know:

Private Property: Lands, Real Estate, Projects:

Q2. What is the European country that you wish to seek asylum in?

Q3. Why did you choose Belgium as an asylum country rather than other EU countries?

Q4. Do you have sufficient information about the geographical, social, demographic, political and legal aspects of life in Belgium, and what is the source of your information?

Q5. Do you intend to reach Belgium legally or illegally?

Q6. Do you sufficient information on illegal immigration to Belgium, and what is the source of your information?

Q 7. Do you have the financial ability to reach Belgium illegally?

Q8. Do not you think it is better to save the money you spend on illegal immigration to Belgium and invest it in a useful work in the Gaza Strip?

Q9. Do you have anything to lose if you leave Gaza to Belgium?

Q10. Do not you fear the harsh treatment of the smugglers and the harsh ways to reach Belgium through sea? Do you have the ability to endure the hardships of smuggling routes? Do you have confidence in the smugglers? Will you think of retreating in case of difficulties in transit countries?

Q11. How will you know the smugglers, how will you communicate with them, and how will you secure the money to be paid to smugglers?

Q12. Do you have an idea about the countries, cities, land and sea routes from which you will flee to Belgium? Where will you stay while waiting for your departure?

Q13. Do you plan to reach Belgium alone, or with all of your family?

Q14. Do you have relatives and acquaintances who are refugees in Belgium, do you have contact with them, and do they encourage you to travel to Belgium?

Q15. Do family, relatives, acquaintances, colleagues and neighbors encourage you to travel to Belgium?

Q16. Will you achieve your ambition to immigrate to Belgium through work, marriage or asylum?

Q17. What information do you have about asylum laws in Belgium, and what is the source of your information? 
Q18. How much do you know about the refugee living conditions in the refugee camps in Belgium; do you have the ability to bear it, the consequences of alienation, and the consequent responsibilities towards the members of your family for the period after you leave them?

019. Do you have a real personal case that calls for your asylum in Belgium, or is the situation in the Gaza Strip generally prompting you to do so?

Q20. Do you have any idea about the expected duration of your asylum application in Belgium, and will you want to suffer the long waiting during your application for asylum or appeal to the decision to deny your asylum application?

Q21. If you are denied a Belgian asylum application, what are the options available to you?

Q22. Are you not concerned about the future of your children, especially the females, from the typical European life in Belgium and its traditions and customs? What are your strategies to preserve the Arab and Islamic life within your family in the context of your life in Belgium?

Q23. Do you think asylum in Belgium will end all your social, economic and political problems, and will you not regret your taking this decision?

Q24. Do you intend to depend on social assistance if you have a refugee status in Belgium or are you going to rely on yourself for a suitable job?

Q25. Would you be willing to learn the languages adopted in Belgium to integrate into the society?

Q26. What influential personal skills do you have which can be useful to the Belgian society, or are you ready to accept the influences of the Belgian society, and secure the gains of the state and society only?

Q27. What is the first country you desire to visit after obtaining the Belgian passport, and why?

Q28. Will Belgium be your second home after Palestine, or will it be just a temporary station until the situation in the Gaza Strip improves?

Q29. If you come to enjoy the comprehensive care of the state and society's appreciation and respect for your humanity, do you think that you will belong to this country intellectually or culturally, or will you just respect it formally and publicly, and will not do anything that harms them?

Q30. Do not fear the criticism of others that you left your occupied country to enjoy the welfare of Belgium instead of steadfastness in your country and contributing to its liberation? 